i otworzyć się na niego. Jest to punkt wyjścia do dobrej homilii i do owocnego udziału w liturgii. $Z$ tych powodów omawiana praca pozostanie zawsze aktualna i przyniesie pożytek wszystkim, którzy wezmą ją do ręki, zwłaszcza jej bezpośrednim adresatom: kaznodziejom, katechetom i tym, którzy pragną głęboko przeżywać liturgię Mszy niedzielnej i świątecznej. Pozycja ta na pewno przyczyni się do tego, aby - zgodnie z zamysłem Autora - nowa ewangelizacja, „nie przestając być w pełni egzystencjalną”, karmiła „obficiej Lud Boży autentycznym słowem Pana, zamiast własnymi tylko myślami kaznodziejów" (s. 8), które pozostaną zawsze niewspółmierne do słowa Bożego. Ładna szata graficzna, kunszt formy i bogactwo treści, dzięki czemu dzieło może służyć za pewien wzorzec, będą niewątpliwie ułatwiać osiągnięcie tego celu i zamienią szybko trud czytania w radość smakowania. Życzyć trzeba tylko sobie, aby następne tomiki tego komentarza mogły ukazać się jak najrychlej.

Kraków

KS. STANISŁAW WRONKA

\title{
PRZEGLĄD BIBLIOGRAFICZNY CZASOPISM
}

\section{ATENEUM KAPŁAŃSKIE}

1997

t. 128

Z. 2

ChrostowsKi W. ks., „,Weź swego jedynego syna, którego miłujesz” (Rdz 22,2). Cierpienie dziecka jako próba wiary rodziców, 222-232;

PISAREK St. ks., Pięćdziesiąty pierwszy Kongres Studiorum Novi Testamenti, 280-282.
1998
t. 130
z. 1

PISAREK St. ks., General Meeting SNTS po raz trzeci w Birmingham (Anglia); 119-124.
1998
t. 130
z. 2

PISAREK ST. ks., Bibliści polscy w Przemyślu i we Lwowie, 285-286.
1998
t. 131
z. 2-3

CHrostowski W. ks., Wolność i postuszeństwo w Biblii, 177-190.

1999

t. 133

z. 1

KUCHARSKa E., Stownictwo biblijne we wspótczesnych kazaniach polskich i niemieckich, 46-58. 


\section{ANALECTA CRACOVIENSIA}

1996 t. 28

CHMIEl J. ks., Une „sociophonie” de la fête de Shavouot - Pentecôte, 219-224; PINDEL R. ks., Gtoszenie ewangelii w kontekście praktyki i myślenia magicznego. Na podstawie Dz 8,4-13; 313-328.

1997 t. 29

CHMIEL J. ks., Biblia aleksandryjska po polsku, 113-115.

\section{COLLECTANEA THEOLOGICA}

$1996 \quad$ Z. 3

GryzIEC P., OFMCONV, Tytuty chrystologiczne w Listach Pasterskich, 5-30; KIEJZA A., OFMCAPT, Postać Baranka w Ap 6,1 i 6,16-17 na tle antropomorficznego obrazu gniewu Boga w Nowym Teastamencie, 31-42; TOMCZAK R. ks., Argument skrypturystyczny $i$ taumaturgiczny $w$ uzasadnieniu boskiego posłannictwa Jezusa z Nazaretu, 43-60.

1996 z. 4

Prokopowicz M., Hathor - „Pani Syjonu” a Biblia. Kilka kluczowych hipotez wokót tradycji Merkawa, 5-50; RosIK M. ks., Relacja Mk-Mt w świetle współczesnych ujęć teorii dwóch źródet, 53-60; TOMCZYK R. ks., Wspótczesna interpretacja funkcji motywacyjnej cudów Jezusa, 61-90; URBAN J., Jezus mistrzem dialogu z innymi religiami, 91-102.

\section{7 z. 1}

BRZEGOWY T. ks., Obraz kultu Bożego w podstawowym dziele deuteronomistycznym, 29-50; CHMIEL J. ks., Pismo święte $w$ duszpasterstwie, 109-115; CZAJKOWSKI M. ks., Pismo święte $w$ dialogu ekumenicznym, 91-107; HARĘZGA St. ks., Droga Stowa Bożego od zrozumienia do inkulturacji, 7-28; PACIOREK A. ks., Alegoria i teoria $w$ egzegezie starożytnego Kościoła, 37-78; PYTEL J. ks., Wykorzystanie Pisma świętego w „Lectio divina”, 51-55; SIKORA A., OFM, Pismo święte w liturgii chrześcijańskiej, 79-107; WODECKI B.,, SVD, Międzynarodowe sympozjum biblijne - Ljubljana 1996, 175-179.
1997
Z. 4

ChrostowsKi W. ks., Życie i twórczość o. Jakuba Wujka (Sympozjum naukowe w Warszawie), 175-178; SEWERYNIAK H. ks., Nauka Soboru Watykańskiego II i wspótczesnej teologii o Objawieniu, 21-34; ZAŁĘSKI J. ks., Czy kobiety powinny milczeć w Kościele (1 Kor 14,34-35), 5-20. 
1998 Z. 1

ChrostowsKI W. ks., „Nic nie zostato, jak tylko samo pokolenie Judy” (2 Krl 17,18b) - czy naprawdę? Zagłada Samarii i Królestwa Izraela oraz jej skutki, 5-22; ZAWADZKI R. ks., Antytezy Kazania na górze (Mt 5,21-48) we wspótczesnej egzegezie, 23-68.

1998 Z. 2

CHROSTOWSKI W. ks., Jerozolima - miasta święte chrześcijan; perspektywa katolicka, 21-40; NowOGÓRSKI P., 300 lat Jerozolimy w kontekście źródel historycznych i archeologicznych, 5-16; SCHUDRICH M., Jerozolima - miasto święte Żydów, 17-20; TAKA-ZUK M., Jerozolima - miasto święte muzulmanów, 59-63.

1998 z. 4

BRIKS P., Struktura Psalmu 98 jako czynnik podkreślający jego teologiczna wymowę, 13-20; GoŁĘBIOWSKI M. bp, Bóg Stwórca i Odkupiciel u Deuteroizajasza, 5-12; PISAREK ST. ks., Uczeń i jego radość $w$ perykopie o winnym krzewie (J 15,1-11), 21-30.

\section{CZĘSTOCHOWSKIE STUDIA TEOLOGICZNE}

\section{5-1996 t.23-24}

CYRAN WŁ. ks., Chrześcijańska konieczność separacji od niewierzacych (Pawłowy midrasz 2 Kor 6,16n na temat Pwt 22,10); MAŁECKI ZDZ. ks., Idea przebaczenia grzechów w Starym Testamencie przed $i$ po niewoli babilońskiej, 127-136; Tronina A. ks., „, Wzniosła Góra Syjon” (KK 55), 137-148; SElEJDAK R. ks., Patriarchowie biblijni jako figury Chrystusa $w$ dziełach egzegetycznych świętego Ambrożego, 155-200; WŁODARCZYK ST. ks., Przewodnie idee teologiczne zwiastowania Maryi (Lk 1,26-28), 149-154.

1997 t. 25

CUDAK A., Gwiazda betlejemska w ujęciu astronomiczno-historycznym, 83-94; Tronina A. ks., Chrystologia Listu do Hebrajczyków, 23-30; WŁODARCZYK ST. ks., Chrystus Zbawiciel i Ewangelizator (Łk 4,1-44), 13-22.

Kraków

zestawił KS. TADEUSZ MATRAS

\section{KSIAŻKI NADESŁANE DO REDAKCJI}

\section{Wydawnictwo KUL}

1. Biblia o Eucharystii, pod red. ks. St. Szymika. Lublin 1997, s. 223.

2. Bibliści polscy. Lublin 1997, s. 58. 